\title{
A COMPARATIVE STUDY OF LIPID PROFILE AMONG YOUNG SMOKERS AND NONSMOKERS
}

\author{
G. Prabhu1, A. Monica², Linto Mathew Thomas 3 , Raja Prabhu J4
}

${ }^{1}$ Reader, Department of General Medicine, Rajah Muthiah Medical College.

2Postgraduate, Department of General Medicine, Rajah Muthiah Medical College.

3Pharm. D (Internship), Department of Pharmacy Practice, Annamalai University.

${ }^{4}$ Pharm. D (Internship), Department of Pharmacy Practice, Annamalai University.

\section{ABSTRACT}

\section{BACKGROUND}

The study was aimed to compare the pattern of lipid profile among young smokers and nonsmokers.

\section{MATERIALS AND METHODS}

Prospective study was carried out to compare the pattern of lipid profile among young smokers and nonsmokers aged between 20-30 years. A total of 100 patients were enrolled in our study in which 50 were smokers and 50 nonsmokers. Patient relevant data was collected from inpatient and outpatient department of medicine, RMMCH. Serum lipid profile was analysed in all the subjects.

\section{RESULTS}

The mean \pm SD of serum total cholesterol was $183 \pm 37.5 / 165.32 \pm 17.38 \mathrm{mg} / \mathrm{dL}$ (smokers/nonsmokers), the mean \pm SD of serum triglyceride is $173.68 \pm 31.08 / 141.1 \pm 13.27 \mathrm{mg} / \mathrm{dL}$ (smokers/nonsmokers), the mean $\pm \mathrm{SD}$ of serum LDL-cholesterol was $114 \pm 28.8 / 107.46 \pm 22.04 \mathrm{mg} / \mathrm{dL}$ (smokers/nonsmokers), levels in smokers was higher compared to levels in control group (nonsmokers). The mean \pm SD of serum of HDL-cholesterol levels in smokers was $48.6 \pm 5.33 / 49.7 \pm 3.54 \mathrm{mg} / \mathrm{dL}$ (smokers/nonsmokers) which was lower compared to levels in control group.

\section{CONCLUSION}

Smoking causes alteration in lipid profile and increased risk of cardiovascular disease.

\section{KEYWORDS}

Smokers, Nonsmokers, Lipid Profile.

HOW TO CITE THIS ARTICLE: Prabhu G, Monica A, Thomas LM, et al. A comparative study of lipid profile among young smokers and nonsmokers. J. Evolution Med. Dent. Sci. 2016;5(79):5860-5862, DOI: 10.14260/jemds/2016/1321

\section{BACKGROUND}

Smoking is now increasing rapidly throughout the developing world and is one of the biggest threats to current and future world health. Tobacco continues to be the second major cause of death in the world.[1] Cigarette smoking is generally considered to be associated with increased risk of a variety of medical disorders. Several studies provide the evidence that tobacco is strongly associated with altering the normal status of the lipid profile.[2-4] Cigarette/bidi leads to increase in the concentration of serum total cholesterol, triglycerides, LDLcholesterol, VLDL-cholesterol and fall in the levels of antiatherogenic HDL cholesterol. By 2030, if current trends continue smoking will kill more than 9 million people annually.[5] Cigarette smoking is believed to cause harmful cardiovascular and atherogenic effects resulting from changes in lipid metabolism. ${ }^{6]}$ Coronary artery disease (CAD) is the most common form of heart disease and the single most important cause of death in the young. Ischaemic heart disease is a result of either reduced blood supply to the heart or an increased myocardial demand.

Financial or Other, Competing Interest: None.

Submission 25-08-2016, Peer Review 19-09-2016,

Acceptance 24-09-2016, Published 30-09-2016.

Corresponding Author:

Dr. G. Prabhu,

\#416, Sai Baba Colony,

Tirupattur-635601,

Vellore District

E-mail: kggprabhu@gmail.com

DOI: $10.14260 /$ jemds/2016/1321
The reduced blood supply is the main cause and it occurs as a result of coronary atherosclerosis. Among the many risk factors associated with the development of atherosclerosis, the principle cause is dyslipidaemia. Various mechanisms leading to lipid alteration by smoking are: (a) Nicotine stimulates sympathetic adrenal system leading to increased secretion of catecholamines resulting in increased lipolysis and increased concentration of plasma free fatty acids (FFA) which further result in increased secretion of hepatic FFAs and hepatic triglycerides along with VLDL- C in the blood stream. (b) Fall in oestrogen levels occurs due to smoking which further leads to decreased HDL - cholesterol. (c) Presence of hyperinsulinaemia in smokers leads to increased cholesterol, LDL-C, VLDL-C, and TG due to decreased activity of lipoprotein lipase. (d) Consumption of a diet rich in fat and cholesterol as well as a diet low in fibre and cereal content by smokers as compared to nonsmokers. There is a response relationship between the number of cigarettes/bidis smoked and cardiovascular morbidity and mortality. $[7,8]$

\section{MATERIALS AND METHODS}

Prospective study was carried out to compare lipid profile among smokers and nonsmokers aged between $20-30$ years. A total of 100 patients were enrolled in our study in which 50 were smokers and 50 nonsmokers. Patient relevant data was collected from inpatient and outpatient department of medicine, RMMCH. Serum lipid profile was statistically analysed in all the subjects. 


\section{Inclusion Criteria}

- Age between 20 to 30 years of both genders.

- Smoking history of $>1$ year.

- All type of tobacco (cigarette, bidis, pipes, etc.) were included.

\section{Exclusion Criteria:}

- Comorbid conditions (diabetes mellitus, hypertension and dyslipidaemia).

- $\quad$ Age $<20$ and $>30$ years.

- Newly started smokers (< 1 yrs.).

- $\quad$ Patients on antilipid drugs (statins, etc.).

\section{RESULTS}

\begin{tabular}{|c|c|c|}
\hline Sex & Smokers & Nonsmokers \\
\hline Male & 50 & 50 \\
\hline Female & - & - \\
\hline Total & $\mathbf{5 0}$ & $\mathbf{5 0}$ \\
\hline \multicolumn{2}{|c|}{ Table 1: Gender wise Distribution } \\
\hline
\end{tabular}

Gender distribution of the study population revealed that $100 \%$ were male patients and none were females

\begin{tabular}{|c|c|c|}
\hline Age & Smokers (n=50) & Nonsmokers (n=50) \\
\hline $20-22$ & 06 & 12 \\
\hline $23-25$ & 12 & 09 \\
\hline $26-28$ & 22 & 17 \\
\hline $29-30$ & 10 & 12 \\
\hline Total & $\mathbf{5 0}(\mathbf{5 0} \%)$ & $\mathbf{5 0}(\mathbf{5 0 \% )})$ \\
\hline \multicolumn{3}{|c|}{ Table 2: Age wise Distribution } \\
\hline
\end{tabular}

Maximum numbers of subjects were in the age group between $26-28$ years (smokers: 22 , nonsmokers: 17 )

\begin{tabular}{|c|c|c|}
\hline $\begin{array}{c}\text { Types of } \\
\text { Tobacco }\end{array}$ & $\begin{array}{c}\text { No. of Patients } \\
(\mathbf{n = 5 0 )}\end{array}$ & Percentage \\
\hline Cigarette & 39 & $78 \%$ \\
\hline Bidi & 10 & $20 \%$ \\
\hline Pipes & 1 & $2 \%$ \\
\hline Total & 50 & $100 \%$ \\
\hline \multicolumn{2}{|c|}{ Table 3: Types of Tobacco used } \\
\hline
\end{tabular}

Among smokers maximum number of subjects used cigarette as type of tobacco (78\%) followed by bidis (20\%) and pipes $(2 \%)$

\begin{tabular}{|c|c|c|}
\hline $\begin{array}{l}\text { Body Mass } \\
\text { index }\end{array}$ & $\begin{array}{c}\text { Smokers } \\
(n=50)\end{array}$ & $\begin{array}{c}\text { Nonsmokers } \\
(n=50)\end{array}$ \\
\hline$<20$ & 16 & 12 \\
\hline $20.1-25$ & 19 & 20 \\
\hline $25.1-30$ & 15 & 17 \\
\hline$>30$ & 0 & 0 \\
\hline Total & 50 & 50 \\
\hline
\end{tabular}

Maximum number of patients enrolled between body mass index of 21-25 (smokers: 19, nonsmokers: 20)

\begin{tabular}{|c|c|}
\hline Duration of Smoking (Years) & No. of Subjects (n=50) \\
\hline $1-2$ & 14 \\
\hline$>2-5$ & 28 \\
\hline$>5$ & 08 \\
\hline \multicolumn{2}{|c|}{ Table 5: Duration of Smoking } \\
\hline
\end{tabular}

$56 \%$ of patients are under the duration period of 2-5 years in smoking followed by $<2$ and $>5$ years

\begin{tabular}{|c|c|c|}
\hline & Control & Smokers \\
\hline Mean & 165.32 & 183 \\
\hline SD & 17.3857 & 37.5 \\
\hline \multicolumn{3}{|c|}{ Table 6: Total Cholesterol $(\mathbf{m g} / \mathbf{d L})$} \\
\hline
\end{tabular}

There was significant increase in serum total cholesterol levels in smokers as compared to nonsmokers $(183 \pm 37.5 / 165.32 \pm 17.38)$.

\begin{tabular}{|c|c|c|}
\hline & Control & Smokers \\
\hline Mean & 141.1 & 173.68 \\
\hline SD & 13.2792 & 31.08 \\
\hline \multicolumn{3}{|c|}{ Table 7: Triglyceride (mg/dL) } \\
\hline
\end{tabular}

Serum triglyceride level was significantly higher in smokers (173.68 \pm 31.08$)$ than in nonsmokers (141.1 \pm 13.27 )

\begin{tabular}{|c|c|c|}
\hline & Control & Smokers \\
\hline Mean & 49.7 & 48.6 \\
\hline SD & 3.54706 & 5.33 \\
\hline \multicolumn{3}{|c|}{ Table 8: HDL (mg/dL) } \\
\hline
\end{tabular}

HDL-cholesterol level was decreased in smokers (48.6 \pm 5.33$)$ when compared with nonsmokers $(49.7 \pm 3.54)$

\begin{tabular}{|c|c|c|}
\hline & Control & Smokers \\
\hline Mean & 107.46 & 114 \\
\hline SD & 22.0493 & 28.8 \\
\hline \multicolumn{3}{|c|}{ Table 9: LDL (mg/dL) } \\
\hline
\end{tabular}

Serum LDL cholesterol was significantly higher in smokers (114 \pm 28.8$)$ than in nonsmokers $(107.46 \pm 22.04)$.

\section{DISCUSSION}

Out of 100 patients enrolled in our study, 50 patients were smokers and 50 were nonsmokers. Overall gender distribution of the study population revealed that $100 \%$ were male patients and none were females. In the present study, we observed that maximum number of subjects were in the age group between 26-28 years (smokers: 22, nonsmokers: 17). Among smokers maximum number of subjects used cigarette as type of tobacco (78\%) followed by bidis (20\%) and pipes (2\%). The present study shows that the maximum number of patients enrolled between body mass index of 20.1-25 (smokers: 19, nonsmokers: 20). As per the study, conducted about $56 \%$ of patients were under the duration period of $>2-5$ years in smoking followed by $<2$ and $>5$ years. The mean \pm SD of serum total cholesterol in the study group was $183 \pm 37.5$ $\mathrm{mg} / \mathrm{dL}$, whereas in control group it was $165 \pm 17.38 \mathrm{mg} / \mathrm{dL}$ which suggests that there was an increase in serum total cholesterol levels in smokers as compared to nonsmokers. Similar study conducted by NS Neki et al[9] where mean \pm SD in smokers and nonsmokers were $181 \pm 28.10 \mathrm{mg} / \mathrm{dL}$ and $164 \pm 20.26 \mathrm{mg} / \mathrm{dL}$, there was an increase in serum total cholesterol levels in smokers as compared to nonsmokers. The mean \pm SD of serum triglycerides was $173.68 \pm 31.08 \mathrm{mg} / \mathrm{dL}$ in smokers and $141.10 \pm 13.27 \mathrm{mg} / \mathrm{dL}$ in nonsmokers. Serum triglycerides were higher in smokers than in nonsmokers. Similar findings were observed by Kavita et al[1] where mean \pm SD in smokers and nonsmokers was found to be $173.44 \pm 46.87$ 
$\mathrm{mg} / \mathrm{dL}$ and $115.9 \pm$ 47.76. The mean \pm SD of serum HDL cholesterol levels in smokers was $48.6 \pm 5.33 \mathrm{mg} / \mathrm{dL}$ whereas in nonsmokers it was $49.7 \pm 3.54 \mathrm{mg} / \mathrm{dL}$, it was observed that HDL cholesterol level was decreased in smokers when compared to nonsmokers. This finding is similar to that of Trupti RR et.al[10] who reported that there is fall in HDL cholesterol level in smokers $[36 \pm 4.36 \mathrm{mg} / \mathrm{dL}]$ when compared to the nonsmokers $[42.50 \pm 5.59 \mathrm{mg} / \mathrm{dL}]$. The mean $\pm \mathrm{SD}$ of serum LDL cholesterol levels was $114 \pm 28.8 \mathrm{mg} / \mathrm{dL}$ in smokers where as in nonsmokers it was $107.46 \pm 22.04 \mathrm{mg} / \mathrm{dL}$ which was similar to the findings of Jagadeesh et al[11] who found it to be higher in smokers $[132.94 \pm 34.56 \mathrm{mg} / \mathrm{dL}]$ compared to nonsmokers [104.36 $\pm 27.05 \mathrm{mg} / \mathrm{dL}]$.

\section{CONCLUSION}

To conclude, smoking causes alteration in lipid profile. Our study shows a relationship between elevation of serum lipids and cigarette smoking. The risk of increase in serum cholesterol with an increase in LDL-cholesterol and decrease in HDL-cholesterol assume a great significance since this has been the pattern associated with coronary artery disease. The exposure of vascular endothelium to atherogenic lipoproteins as a consequence of impaired clearance of triglyceride rich lipoproteins and the low levels of HDL-cholesterol in cigarette smokers may provide a mechanism whereby smoking increases the risk of developing atherosclerotic plaques and coronary artery disease. Cessation of smoking not only reverses lipid changes but also vascular diseases especially coronary artery disease. Passive smokers are prone to get the same abnormality as demonstrated in literature. It is the need of the hour to understand the requirement of intense educational programmes regarding the adverse effects of smoking and also amend law to prohibit smoking in public places to curb the health hazards of smoking.

\section{LIMITATION OF THE STUDY}

- $\quad$ Need to have a multicentre approach with different group of population [urban and rural] with a large population in the study and control group to have more preferred results.
- Effect of type of tobacco used was not clearly assessed for the lipid alteration.

\section{REFERENCES}

1. Kavita, Gohel P, Nanavati MG, et al. A comparative study of lipid profile among smokers and nonsmokers. Int J Res Med 2014;3(4):76-81.

2. Arslan E, Yakar T, Yavaşoğlu I. The effect of smoking on mean platelet volume and lipid profile in young male subjects. Anadolu Kardiyol Derg 2008;8(6):422-5.

3. Criqui $\mathrm{MH}$, Wallace RB, Heiss G, et al. Cigarette smoking and plasma high-density lipoprotein cholesterol. The lipid research clinics program prevalence study. Circulation 1980;62(4 Pt 2):70-6.

4. Cuesta C, Sánchez-Muniz FJ, García-La Cuesta A, et al. Effects of age and cigarette smoking on serum concentrations of lipids and apolipoproteins in a male military population. Atherosclerosis 1989;80(1):33-9.

5. Terry PD, Rohan TE. Cigarette smoking and the risk of breast cancer in women: a review of the literature. Cancer Epidemiol Biomarkers Prev 2002;11(10 Pt 1):953-71.

6. Rosenson RS. Low level of HDL-cholesterol (hypoalphalipoproteinemia). An approach to management. Arch Intern Med 1993;153(13):1528-40.

7. Kannel WB. Update on the risk of cigarette smoking in coronary artery disease. Am Heart J 1981;101(3):319-28.

8. Wynder EL, Harris RE, Haley NJ. Population screening for plasma cholesterol. Community based results from Connecticut. Am Heart J 1989;117(3):649-56.

9. Neki NS. Lipid profile in chronic smokers - a clinical study. Journal, Indian Academy of Clinical Medicine 2002; 3(1):51-4.

10. Trupti RR, Ramakrishna MR, Desai RD, et al. Comparative study of effect of lipid profile in smokers and nonsmokers of age group of 40-50 years. International Journal of Research in Health Sciences 2015;3(1):1-4.

11. Ega JK, Ega LK. Comparative study of lipid profile in young smokers and nonsmokers. J Chem Pharm Res 2016;8 (2):513-25. 